\title{
Hydrologic similarity among catchments under variable flow conditions
}

\author{
S. Patil ${ }^{1}$ and M. Stieglitz ${ }^{1,2}$ \\ ${ }^{1}$ School of Civil and Environmental Engineering, Georgia Institute of Technology, Atlanta, GA, USA \\ ${ }^{2}$ School of Earth and Atmospheric Sciences, Georgia Institute of Technology, Atlanta, GA, USA
}

Received: 14 October 2010 - Published in Hydrol. Earth Syst. Sci. Discuss.: 28 October 2010

Revised: 4 March 2011 - Accepted: 14 March 2011 - Published: 23 March 2011

\begin{abstract}
An assessment of regional similarity in catchment stream response is often needed for accurate predictions in ungauged catchments. However, it is not clear whether similarity among catchments is preserved at all flow conditions. We address this question through the analysis of flow duration curves for 25 gauged catchments located across four river basins in the northeast United States. The coefficient of variation of streamflow percentiles is used as a measure of variability among catchments across flow conditions. Results show that similarity in catchment stream response is dynamic and highly dependent on flow conditions. Specifically, within each of the four basins, the coefficient of variation is high at low flow percentiles and gradually reduces for higher flow percentiles. Analysis of the inter-annual variation in streamflow percentiles shows a similar reduction in variability from low flow to high flow percentiles. Greater similarity in streamflows is observed during the winter and spring (wet) seasons compared to the summer and fall (dry) seasons. Results suggest that the spatial variability in streamflow at low flows is primarily controlled by the dominance of high evaporative demand during the warm period. On the other hand, spatial variability at high flows during the cold period is controlled by the increased dominance of precipitation input over evapotranspiration. By evaluating variability over the entire range of streamflow percentiles, this work explores the nature of hydrologic similarity from a seasonal perspective.
\end{abstract}

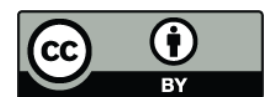

Correspondence to: S. Patil

(sopan.patil@gatech.edu)

\section{Introduction}

A number of problems in hydrology require estimation of regional similarity in catchment stream response. These include: regional flood frequency analysis (Acreman and Sinclair, 1986; Burn, 1997; Merz and Blöschl, 2005), parameter regionalization for lumped hydrologic models (Burn and Boorman, 1993; Merz and Blöschl, 2004), regional low flow predictions (Nathan and McMahon, 1990; Laaha and Blöschl, 2006), and water quality assessment (Wolock et al., 2004). A common goal in many of these studies involves the transfer of hydrologic information, such as flood quantiles (Burn and Goel, 2000), model parameters (Oudin et al., 2008; Zhang and Chiew, 2009) etc., from gauged to ungauged catchments. Unfortunately, a universally accepted metric of hydrologic similarity among catchments does not exist yet (McDonnell et al., 2007; Wagener et al., 2007).

Several approaches for quantification of catchment hydrologic similarity have been documented in the hydrology literature. One widely used approach involves the use of similarity in catchment physiographic characteristics. Acreman and Sinclair (1986) grouped 186 catchments in Scotland into five homogeneity regions based on six basin characteristics, viz., drainage area, stream frequency, channel slope, mean annual rainfall, fraction of basin covered by lakes and soil type index. Wiltshire (1986) grouped 376 British catchments into five homogeneous regions based on catchment attributes such as basin area, average annual rainfall and urban fraction. Burn and Goel (2000) grouped catchments in central India for flood frequency estimation using attributes such as catchment area, stream length and main channel slope. Wolock et al. (2004) used the hydrologic landscapes concept of Winter (2001) to group 43931 catchments in United States into 20 regions based on identification of similarities in topography

Published by Copernicus Publications on behalf of the European Geosciences Union. 


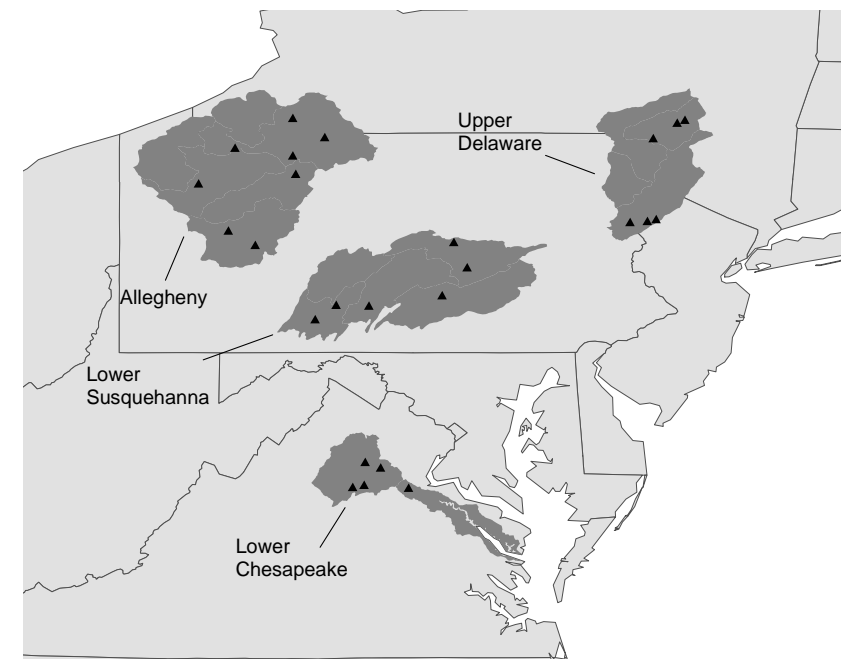

Fig. 1. Four River basins and the 25 nested catchments in northeast United States.

(\% slope), soil (\% sand) and climate (annual rainfall, potential evapotranspiration).

Another approach for characterizing regional similarity among catchments uses hydrologic information directly derived from streamflow data of gauged catchments. Mosley (1981) clustered 174 New Zealand catchments into hydrologically homogeneous regions based on similarities in specific mean annual flow and the coefficient of variation of instantaneous flood discharge. Ogunkoya (1988) used parameters such as runoff coefficient, flow variability index, annual runoff, etc. that were directly obtained from the daily streamflow data to group catchments in southwest Nigeria into five hydrologic regions. Kachroo et al. (2000) used the combined data of annual maximum flood and physiographic attribute information from 77 gauged catchments in Tanzania to partition the country into 12 homogeneous regions.

Regardless of the approach used, the controls on hydrologic similarity are still poorly understood. Moreover, it is also not clear whether similarity among two or more catchments is preserved across flow conditions. For instance, it is possible that streamflow similarity among catchments depends on hydrologic controls that are sensitive to seasonal fluctuations in flow regimes. In such a case, one might expect the similarity among catchments to be dynamic and vary with flow conditions. In this study, we explore the controls on hydrologic similarity by considering four river basins in the northeast United States, and use the data from multiple gauged catchments within each basin. The criteria for selecting catchments within each basin are similarity in the long-term annual rainfall and runoff. We use longterm daily streamflow records from 25 gauged catchments located within these four river basins and analyze the spatial and inter-annual variability in their streamflow percentiles. Our a priori assumption is that since catchments within each chosen basin are in close proximity and also similar in annual rainfall and runoff, their stream response is likely to be similar across flow conditions. The questions addressed in this study are: (1) does the stream response similarity among catchments exist under all flow conditions, and if not, (2) under which conditions are the catchments likely to be similar in hydrologic response.

\section{Data}

We consider four river basins located in the northeast United States, viz., Allegheny, Upper Delaware, Lower Susquehanna, and Lower Chesapeake (Fig. 1). Streams in the Upper Delaware, Lower Susquehanna, and Lower Chesapeake basins flow eastwards into the Atlantic Ocean, while those in the Allegheny basin flow westwards to join the Mississippi river and ultimately flow into the Gulf of Mexico. The Allegheny basin is located within the Allegheny plateau, and is underlain by sedimentary rocks that are fractured, faulted and folded at several locations. The channel bedrock consists of weathered rock material, Quaternary glacio-fluvial deposits, and alluvium (Anderson et al., 2000). Soils in areas of steep slopes are shallow and poorly drained, while the soils on gentler slopes are deep, well drained and fertile. The Upper Delaware basin is located in the eastern part of the Allegheny plateau and the northern part of the Appalachian plateau. The existing topography of the river basin was formed by recent glaciations, and the parent material is composed of glacial till deposits in the uplands (Ayers et al., 1994). The Lower Susquehanna basin contains Precambrian to Triassic bedrocks that are structurally complex and lithologically diverse. The structural complexity across its landscape is the result of periods of uplift and collision of continental plates (Risser and Siwiec, 1996). The Lower Chesapeake basin consists of Rappahannock River and its tributaries that drain into the Chesapeake Bay. This basin drains parts of the Blue Ridge and Piedmont physiographic provinces in northeastern Virginia. The sediment in this watershed is derived from the weathered felsic crystalline rocks in the Blue Ridge and Piedmont (Nelson, 1960).

The US Geological Survey's Hydro-Climate Data Network (HCDN) (Slack et al., 1993) is used as the database for catchment selection. The HCDN primarily consists of data for catchments that are not severely affected by human activity. While the streamflow records in HCDN span from 1874 to 1988 , most catchments have consistent and continuous records from water year 1970 onwards. Within each basin, we examine all the gauged catchments that are part of the HCDN database. Daily streamflow for each catchment is obtained for the water years 1970 to 1988 (i.e., 1 October 1969 to 30 September 1988). Monthly precipitation data for each catchment is obtained from the hydro-climatic dataset developed by Vogel and Sankarasubramanian (2005). Average annual rainfall $\left(P_{\mathrm{ann}}\right)$ and average annual discharge 

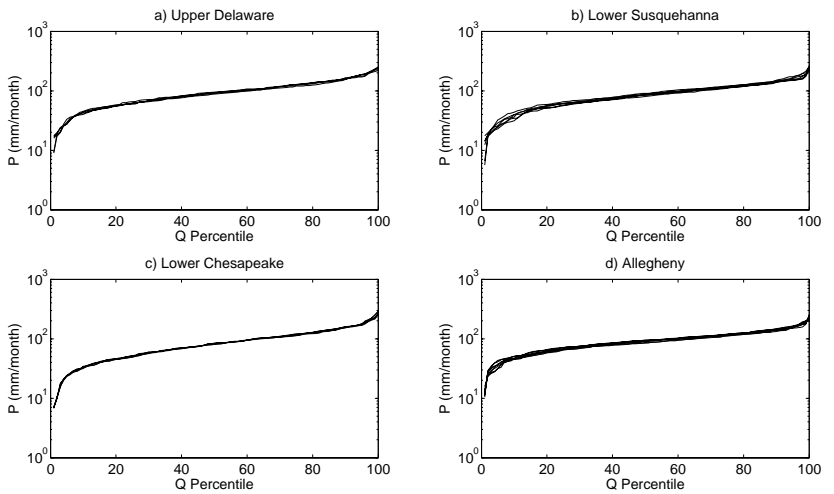

Fig. 2. Precipitation Duration Curves of all the catchments within (a) Upper Delaware, (b) Lower Susquehanna, (c) Lower Chesapeake, and (d) Allegheny basin.

( $\left.Q_{\text {ann }}\right)$ are calculated for each catchment using the data spanning 19 years. The coefficient of variation $(\mathrm{CV}=$ Standard deviation/Mean) of $P_{\text {ann }}$ and $Q_{\text {ann }}$ is then calculated for each basin. If the CV of either $P_{\text {ann }}$ or $Q_{\text {ann }}$ exceeds 0.1 in a basin, the outlier catchments with $P_{\text {ann }}$ or $Q_{\text {ann }}$ value farthest from the basin mean are eliminated and the $\mathrm{CV}$ values are recalculated. The criterion of $\mathrm{CV}<0.1$ ensures that, within each of the four basins, only those catchments are chosen that have homogeneity in their long-term annual rainfall and streamflow. Based on the above criterion, we found 25 gauged catchments among our four basins with drainage areas varying from $65 \mathrm{~km}^{2}$ to $4163 \mathrm{~km}^{2}$ (see Fig. 1). The average annual rainfall of the selected catchments for the water years 1970-1988 ranged from $1025 \mathrm{~mm}$ to $1230 \mathrm{~mm}$. Figure 2 shows the precipitation duration curves (percentile value vs. precipitation amount) of the 25 catchments. These curves are similar for catchments within each basin and suggest the existence of similarity in the precipitation input patterns. Estimates of monthly potential evapotranspiration (PET) for each catchment are obtained from the Vogel and Sankarasubramanian (2005) dataset, where they used the PET formulation introduced by Hargreaves and Samani (1982). The baseflow and the baseflow index (BFI), i.e., baseflow/total flow, of catchments are calculated using the one parameter singlepass digital filter method of baseflow separation (Arnold and Allen, 1999; Eckhardt, 2008). The physiographic and hydroclimatic information of the catchments is summarized in Table 1 .

\section{Methods}

\subsection{Flow duration curve}

We use the variability in streamflow percentiles of flow duration curves (FDC) (Searcy, 1959; Vogel and Fennessey, 1994, 1995; Smakhtin, 2001) to examine similarity among catchments under varying flow conditions. The FDC graph- ically illustrates the amount of time (expressed as a percentage) a specific streamflow value is equaled or exceeded in a catchment within a specified period of hydrologic record. Traditionally, FDC is constructed over an entire chosen period of hydrologic record (Searcy, 1959). However, this makes the FDC sensitive to the period chosen, especially the exceptionally dry or wet years in the record, and might not reflect the typical hydrologic behavior of the catchment. To reduce the bias of a chosen period of record, Vogel and Fennessey (1994) suggested an alternate method for constructing FDC that is based on inter-annual calculations. Following Vogel and Fennessey (1994), considering the daily streamflow record of $n$ years, the flow percentile values are calculated for each of the $n$ years separately. The median of all $n$ values for each flow percentile is then calculated and the median FDC is constructed. Through this procedure, the FDC is less sensitive to the exceptional years of flood or drought in the record, and we obtain the FDC for a typical (or median) year for the catchment. A detailed review of the physical interpretation and water resources applications of the FDC is provided in Vogel and Fennessey (1995).

\subsection{Assessing variability in flow percentiles}

The median FDCs of all 25 catchments are constructed with $n=19$ years. Flow percentiles are obtained for all integer values ranging from 0 (minimum flow) to 100 (maximum flow). Within each basin, we obtain the $\mathrm{CV}$ value of each flow percentile from the median FDCs of all the catchments. The CV of flow percentiles is used as a measure of variability among catchments across flow conditions. Since the CV is a dimensionless metric, we consider it more suitable for comparing variability across a wide range of streamflow magnitudes. We further measure the inter-annual temporal variability of flow percentiles by calculating the $\mathrm{CV}$ of each individual percentile among all the 19 years of record. The inter-annual CV of the flow percentiles is measured individually for each of the 25 catchments.

\section{Results}

\subsection{Spatial and temporal variability in streamflow across flow percentiles}

Figure 3 shows the FDCs of all 25 catchments, grouped by their respective river basin. The FDCs are plotted as streamflow value vs. the streamflow percentile (i.e., the amount of time the streamflow is below that particular value). The high flow percentiles appear similar within all the four basins. The low flow percentiles appear more divergent from each other, especially in the Upper Delaware and Lower Susquehanna basins. Figure 4 shows the $\mathrm{CV}$ of all streamflow percentiles for the four basins and quantifies the intra-basin variability in streamflow percentiles. In all the four basins, CV is high at low flow conditions and trends lower for high flow 
Table 1. Details of the 25 catchments within the four river basins.

\begin{tabular}{|c|c|c|c|c|c|c|c|c|}
\hline River Basin & $\mathrm{CV}\left(Q_{\mathrm{ann}}\right)$ & $\mathrm{CV}\left(P_{\mathrm{ann}}\right)$ & $\begin{array}{l}\text { USGS } \\
\text { Station }\end{array}$ & $\begin{array}{r}\text { Area } \\
\left(\mathrm{km}^{2}\right)\end{array}$ & $\begin{array}{r}\text { Slope } \\
\left(\mathrm{m} \mathrm{km}^{-1}\right)\end{array}$ & BFI & $\begin{array}{l}\text { Annual } \\
Q(\mathrm{~mm})\end{array}$ & $\begin{array}{l}\text { Annual } \\
P(\mathrm{~mm})\end{array}$ \\
\hline \multirow{6}{*}{ Upper Delaware } & \multirow{6}{*}{0.09} & \multirow{6}{*}{0.03} & 01420500 & 623.9 & 6.3 & 0.657 & 842.3 & 1118.4 \\
\hline & & & 01413500 & 422.0 & 2.9 & 0.662 & 702.9 & 1172.9 \\
\hline & & & 01414500 & 65.2 & 22.8 & 0.667 & 783.7 & 1162.0 \\
\hline & & & 01439500 & 302.9 & 6.6 & 0.708 & 750.2 & 1150.1 \\
\hline & & & 01440400 & 170.6 & 15.3 & 0.685 & 786.2 & 1227.9 \\
\hline & & & 01440000 & 165.7 & 7.1 & 0.697 & 641.0 & 1152.3 \\
\hline \multirow{6}{*}{ Lower Susquehanna } & \multirow{6}{*}{0.09} & \multirow{6}{*}{0.05} & 01555000 & 779.3 & 3.6 & 0.710 & 579.7 & 1055.8 \\
\hline & & & 01555500 & 419.4 & 2.1 & 0.617 & 542.1 & 1077.1 \\
\hline & & & 01562000 & 1957.2 & 1.3 & 0.632 & 479.3 & 1200.8 \\
\hline & & & 01560000 & 445.3 & 8.1 & 0.590 & 519.9 & 1194.8 \\
\hline & & & 01564500 & 530.7 & 2.7 & 0.578 & 457.2 & 1154.6 \\
\hline & & & 01568000 & 517.8 & 1.4 & 0.628 & 556.6 & 1099.4 \\
\hline \multirow{5}{*}{ Lower Chesapeake } & \multirow{5}{*}{0.08} & \multirow{5}{*}{0.02} & 01664000 & 1605.1 & 1.8 & 0.658 & 420.8 & 1047.4 \\
\hline & & & 01667500 & 1222.0 & 2.8 & 0.669 & 442.9 & 1064.9 \\
\hline & & & 01663500 & 743.0 & 5.6 & 0.668 & 459.9 & 1025.1 \\
\hline & & & 01666500 & 463.4 & 6.6 & 0.670 & 489.4 & 1063.4 \\
\hline & & & 01668000 & 4131.9 & 1.3 & 0.628 & 399.4 & 1075.4 \\
\hline \multirow{8}{*}{ Allegheny } & \multirow{8}{*}{0.07} & \multirow{8}{*}{0.04} & 03011020 & 4162.9 & 1.0 & 0.663 & 622.2 & 1087.6 \\
\hline & & & 03010500 & 1423.9 & 2.1 & 0.653 & 633.6 & 1025.3 \\
\hline & & & 03015500 & 831.0 & 1.4 & 0.603 & 688.7 & 1175.4 \\
\hline & & & 03011800 & 120.1 & 6.7 & 0.661 & 595.5 & 1128.0 \\
\hline & & & 03020500 & 776.7 & 1.6 & 0.615 & 672.1 & 1107.7 \\
\hline & & & 03028000 & 163.1 & 7.9 & 0.656 & 738.9 & 1148.0 \\
\hline & & & 03032500 & 1366.9 & 1.0 & 0.637 & 631.2 & 1130.5 \\
\hline & & & 03034500 & 226.3 & 3.2 & 0.595 & 661.5 & 1160.0 \\
\hline
\end{tabular}

percentiles (except for extremely high flow). However, the pattern of variability reduction is different within each river basin. In the Upper Delaware and Allegheny basins, the CV drops fast at lower percentiles $(<20 \%)$, stays low at intermediate percentiles (approximately from $20 \%$ to $90 \%$ ), and then increases again for extremely high flow percentiles. In Lower Susquehanna basin, the $\mathrm{CV}$ reduces almost at a constant rate until about 95th percentile and then increases sharply near the highest flow percentiles. In the Lower Chesapeake basin, the CV drops rapidly from 0th percentile (minimum flow) to about 10th percentile, increases again until about 25th percentile and then continues its gradual decrease. The lowest $\mathrm{CV}$ values are observed in the range of 40th and 75th percentiles in the Lower Chesapeake basin.

A sudden increase in the CV is observed at extremely high flow percentiles ( $>90 \%$ ) in the Upper Delaware, Lower Susquehanna and Allegheny basins (Fig. 4). A sharp rise in $\mathrm{CV}$, however, is not observed at high flow percentiles in the Lower Chesapeake basin, where there is a more gradual increase. In all the four basins, difference between the highest and the lowest CV values is significant (Fig. 4). In the Upper Delaware, Lower Chesapeake, and Allegheny basins, $\mathrm{CV}$ reduces from the highest value of about 0.3 to the low-
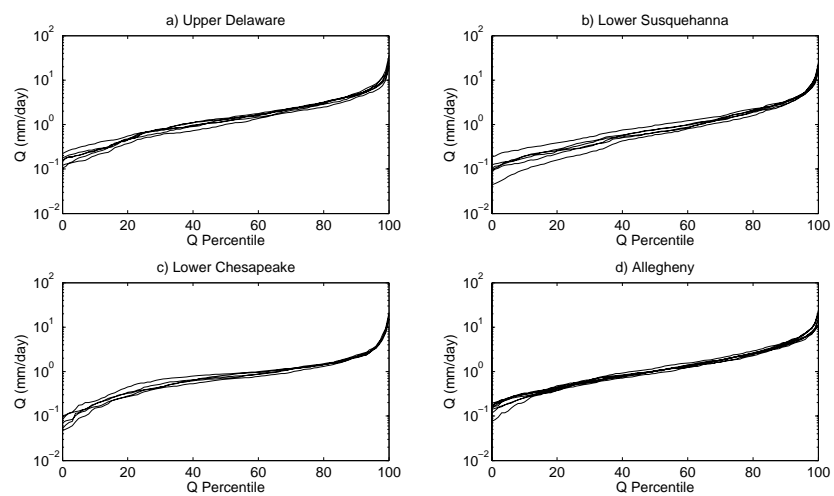

Fig. 3. Flow Duration Curves of all the catchments within (a) Upper Delaware, (b) Lower Susquehanna, (c) Lower Chesapeake, and (d) Allegheny basin.

est value near 0.1. In the Lower Susquehanna basin, the highest CV is about 0.45 , while the lowest CV is approximately 0.05 . Figure 5 shows the inter-annual CVs of flow percentiles for each individual catchment. High CV is observed at the low flow and extremely high flow percentiles, 

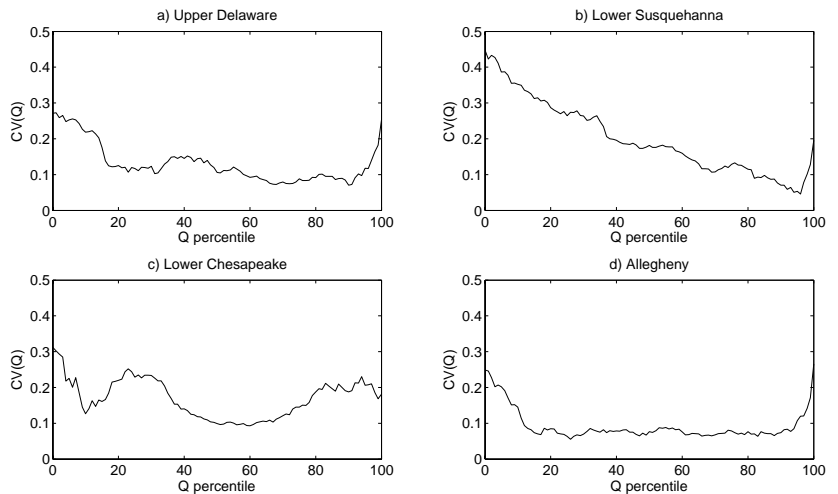

Fig. 4. Coefficients of variation of catchment streamflow percentiles within (a) Upper Delaware, (b) Lower Susquehanna, (c) Lower Chesapeake, and (d) Allegheny basin.

whereas low $\mathrm{CV}$ is observed at intermediate flow percentiles for the majority of catchments. There are a few catchments, especially within the Lower Susquehanna basin, that are exceptions to this trend. In those catchments, the $\mathrm{CV}$ in the 20th-60th percentile range is higher than the CV for flows below 20th percentile. Moreover, the relationships between inter-annual CVs and catchment properties such as drainage area and baseflow index (BFI) have considerable scatter and no significant trends are observed (result not shown). Overall, the intra-basin differences in inter-annual variability of catchment stream response exist mostly at lower flow percentiles. The magnitudes of CVs are more similar at higher flow percentiles.

Since the CV is a ratio of standard deviation and mean, we also analyze both these entities separately in order to explore the relative influence of each property on the $\mathrm{CV}$ values from low to high flow percentiles. Figure 6 shows the spatial mean (solid line) and standard deviation (dashed line) of all the flow percentiles for catchments in each of the four river basins. The mean value varies smoothly across the flow percentiles and appears similar to the flow duration curves shown in Fig. 3. On the other hand, the variations in standard deviation across flow percentiles do not follow the similar pattern as mean values and appear more fluctuating. From low to high flow percentiles, the mean increases at a faster rate than standard deviation, thus decreasing the $\mathrm{CV}$ values at higher flow percentiles. However, at extremely high flow percentiles (>90\%), the standard deviation increases at a faster rate than mean, and increases the $\mathrm{CV}$ values at those flow percentiles. Similar trends as in Fig. 6 are observed for temporal variability of mean and standard deviation at individual catchments across flow percentiles (result not shown).
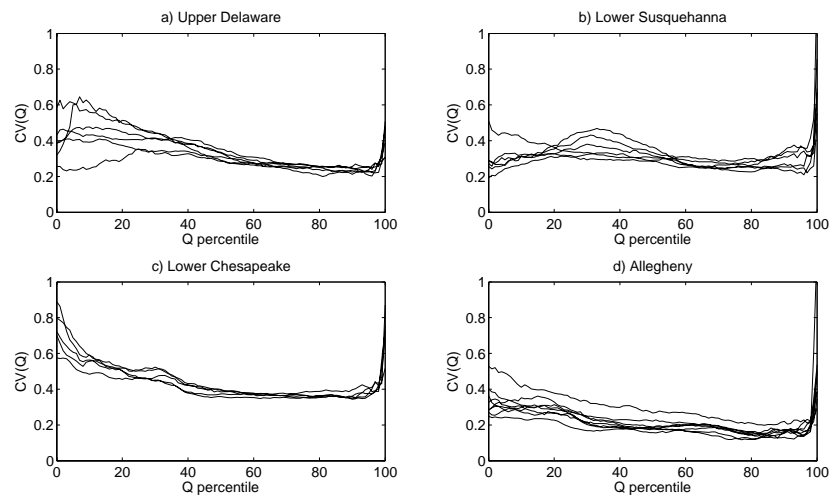

Fig. 5. Inter-annual coefficients of variation of streamflow percentiles for all the 25 catchments within (a) Upper Delaware, (b) Lower Susquehanna, (c) Lower Chesapeake, and (d) Allegheny basin.

\subsection{Seasonal variations in the hydrologic similarity among catchments}

Next, we seek to identify the seasonal trends in similarity. Within each basin, we select two catchments that are located closest to each other. The condition of closest proximity is to ensure that the catchment pair has a high likelihood of receiving similar rainfall input at daily time-scale. Figure 7 shows the comparison of daily hydrographs of the two selected catchments within each basin for water year 1973. Streamflows of catchments in the Upper Delaware, Allegheny and Lower Chesapeake basins have similar magnitudes and fluctuate almost in unison from mid-November to mid-June period (Fig. 7a, c, d) when the flow is typically high, and suggests that these catchments are responding to same climatic inputs. On the other hand, the hydrologic response of catchments during the summer and early fall months is dissimilar when the flow is typically low. In contrast to the other three basins, the dissimilarity in streamflows for the catchment pair in Lower Susquehanna basin persists from February to November period (see Fig. 7b).

\section{Discussion}

Results suggest that the hydrologic response of two or more catchments within a region does not remain similar across flow conditions (Fig. 4). The intra-basin variability in streamflow among catchments is high at low flow percentiles, and the variability reduces at higher flow percentiles. The relationship between CV and streamflow percentiles is unique for catchments within each of the four basins (Fig. 4) and is suggestive of the conditions at which the similarity/dissimilarity among the catchments is manifested. As seen in Fig. 7, the hydrographs of catchments in Upper Delaware, Allegheny and Lower Chesapeake basins are similar during the winter and spring periods, while most 

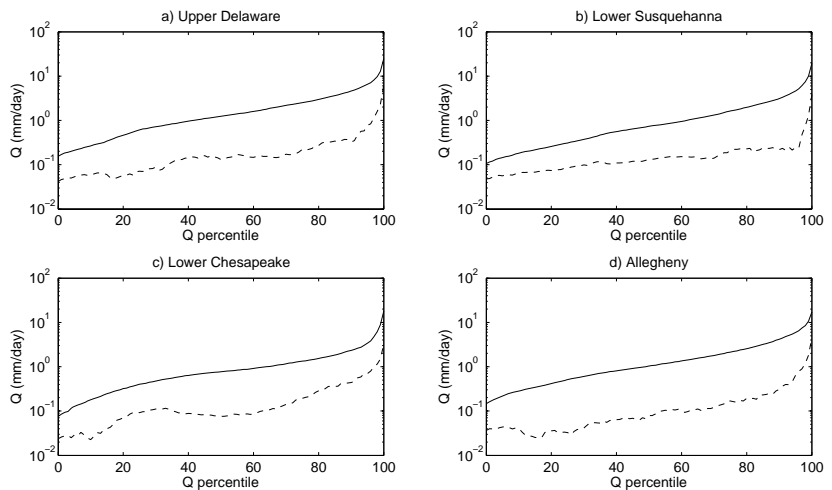

Fig. 6. Spatial mean (solid line) and standard deviation (dashed line) of catchment streamflow percentiles within (a) Upper Delaware, (b) Lower Susquehanna, (c) Lower Chesapeake, and (d) Allegheny basin.

of the dissimilarity occurs during the low flow period in summer. Figure 8 shows the average monthly values of streamflow, precipitation and PET of a sample catchment within each of the four basins. In all the four basins, high flow period is characterized by low ET demand, whereas the low percentile flows mostly occur when the water balance of a catchment is heavily influenced by the high ET demand from atmosphere. Thus, the dominance of ET demand becomes a controlling factor on the magnitude and spatial variability of streamflow during the low flow summer period; whereas the dominance of precipitation input controls the streamflow magnitudes and variability during the higher flow periods in winter. However, the streamflows of catchments in the Lower Susquehanna basin exhibit greater dissimilarity than the catchments in other three basins. As seen in Fig. 7b, the similarity in streamflow is limited only to the early winter period when the ET demand from atmosphere is the lowest. From mid-November to April period, the peaks of hydrographs are similar between the two catchments, but their recession characteristics start to show differences as the year progresses (Fig. 7b). Therefore, dissimilarity in streamflows over a longer period results in higher $\mathrm{CV}$ values across low and intermediate streamflow percentiles within the Lower Susquehanna basin (Fig. 4b).

The seasonal fluctuations in streamflow variability also suggest that different physical factors govern the spatial streamflow patterns at different periods within a year. During low flow conditions, typically in summer when the ET demand is high (Fig. 8), water fluxes are predominantly vertical (Tromp-van Meerveld and McDonnell, 2006; James and Roulet, 2007), and the spatial patterns of soil moisture are unorganized and strongly influenced by the local terrain (Grayson et al., 1997; Stieglitz et al., 2003). At these low flow conditions, disparate regions within a catchment are hydrologically disconnected (due to a lack of lateral water movement) and the catchment discharge is most likely
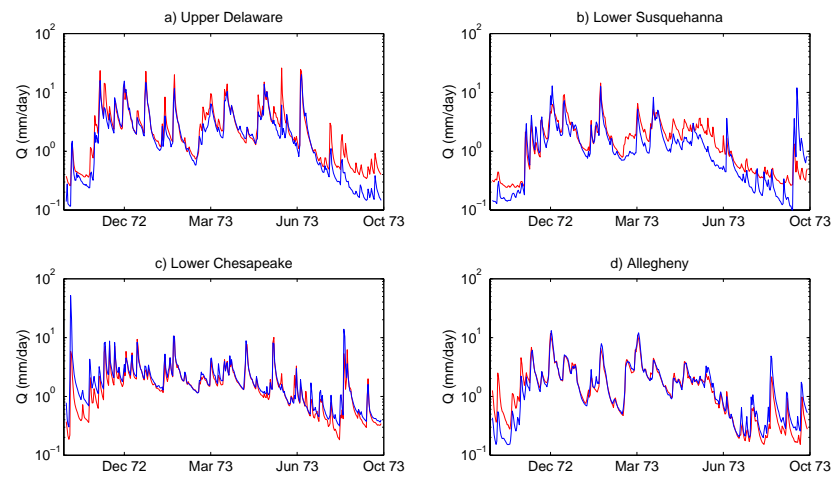

Fig. 7. Hydrograph comparison of the two selected catchments for water year 1973 within (a) Upper Delaware, (b) Lower Susquehanna, (c) Lower Chesapeake, and (d) Allegheny basin.

controlled by the geologic factors such as the intricacies of landscape micro-topography, subsurface structure, soil texture and structure, etc. This local geologic control on hydrologic conditions can result in higher variability of streamflow response. However, even though geologic properties of the landscape might be playing an important role in streamflow variability at low flow conditions, a further examination of geologic data (permeability, \% organic matter, \% clay content) in all our 25 study catchments showed that a large variability exists in soil properties within each catchment, and no distinct differences are observed between catchments that can be quantitatively attributed to the variability at low flows. On the other hand, increased similarity among catchments at higher flow percentiles indicates a shift from "local" to "non-local" (climatic) controls as the catchments transition from low flow to high flow conditions. As the atmospheric evaporative demand reduces, a higher proportion of the precipitation gets converted into streamflow (Fig. 8). The high flow conditions reflect the period when the lateral fluxes of water are dominant (Grayson et al., 1997), the near surface and subsurface flow paths are connected (Meyles et al., 2003; Uchida et al., 2004; Tromp-van Meerveld and McDonnell, 2006; Stieglitz et al., 2003), and the streamflow variability is increasingly controlled by larger scale climatic forcing.

The CV values increase rapidly for the highest flow percentiles ( $>90$ th percentile). This increase is observed not only in the spatial variation of streamflows (Fig. 4) but also in the inter-annual streamflows in individual catchments (Fig. 5). A potential cause for this rapid increase could be that during the very high flow events the hydraulic properties of stream channels play an important role in controlling the streamflow. The control of these hydraulic properties can: (1) increase the variability in space (between catchments) at any given year, and (2) increase the variability in time (yearto-year) within a single catchment. Another potential cause for increased CV values could be the dependence of peak flow variability on catchment drainage areas (Smith, 1992; Blöschl and Sivapalan, 1997; Eaton et al., 2002). However, 
examination of the relationship between the $\mathrm{CV}$ values and drainage areas of our study catchments showed no clear trend in this relationship at any flow condition. We further examined the timing of peak flow events in our catchments to verify whether high flow variability is caused by peak flows occurring in response to local-scale convective storms in summer months. We found that majority of the peak flow events occur during the winter and spring period when larger scale frontal precipitation events are more likely.

The choice of using CV as our variability metric directly affects how the controls on streamflow similarity are interpreted. The $\mathrm{CV}$ measures relative variability (around the mean value), and therefore, high $\mathrm{CV}$ at low flow percentiles can be expected due to small mean values. With an increase in streamflow from dry to wet conditions, the mean flow value increases steadily while the standard deviation increases at a much slower rate and causes the $\mathrm{CV}$ value to decrease from low flows to high flows. Although we attribute these changes in $\mathrm{CV}$ to shift in hydrologic controls under variable flow conditions, it can be argued that our results do not genuinely reflect the shifting hydrologic controls and are an artifact caused by use of CV as a similarity measure. To test this, we consider 25 synthetically generated random time-series, each representing one of our 25 study catchments by having the same probability distribution (lognormal) as the actual streamflow series. We repeat our analyses on these 25 synthetic time-series to obtain the spatial and temporal CV patterns, similar to those shown in Figs. 4 and 5. Figure 9 shows the spatial and temporal CV patterns of the synthetic time-series within the Lower Susquehanna basin. The synthetic series show that the intermediate percentiles have low $\mathrm{CV}$ values, while the extreme percentiles have high CVs. However, when compared with actual streamflow in Lower Susquehanna basin (Figs. 4b and 5b), the CV patterns of the synthetic series (Fig. 9) are distinctly different. Specifically, the synthetic time-series is unable to capture the monotonously decreasing spatial CVs of actual streamflows in Lower Susquehanna basin (Fig. 4b). Moreover, the CV patterns obtained by these synthetic series are similar (and indistinguishable) in all the four basins (results not shown) and do not inform us about the differences in CV patterns across the four basins. Therefore, although the random series display somewhat similar CV trends as the actual streamflow series (due to similar probability distributions), the changes in CV values observed in our study (Figs. 4 and 5) are most likely caused due to the underlying shift in hydrologic controls, and not an artifact of our methodology.

The results of this study have ramifications for predicting streamflow in ungauged catchments. Specifically, during low flows, the variability of streamflow among catchments is high, and the predictive capability at ungauged catchments using information from nearby gauged catchments is likely to be low. However, although the relative variability is high at low flows, the variability in absolute streamflow values will be low during the low flow periods. Therefore, depending on
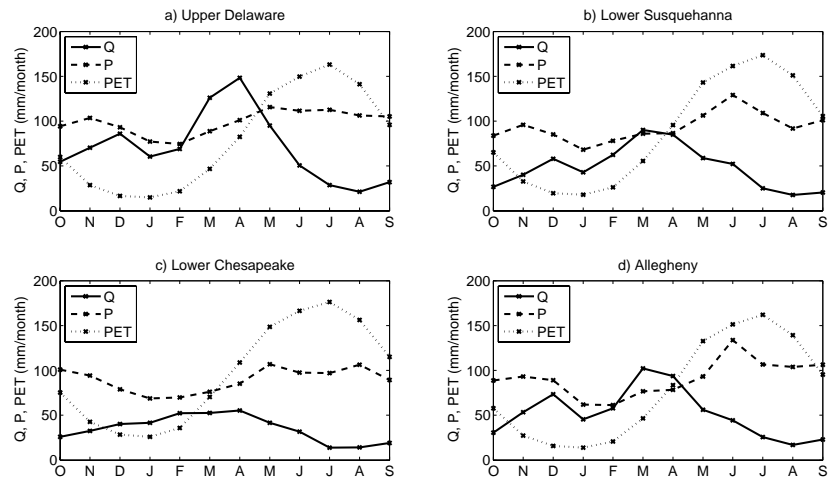

Fig. 8. Average monthly values of streamflow, precipitation and potential evapotranspiration of a sample catchment in (a) Upper Delaware, (b) Lower Susquehanna, (c) Lower Chesapeake, and (d) Allegheny basin.

the error tolerance that is acceptable to the end user, streamflows at low flow periods can be simulated with limited success. During wet conditions, the variability of streamflow among catchments is low, which increases the similarity among catchments within a region and improves the prediction capability at ungauged catchments. This suggests that regions with predominantly wet conditions, i.e., humid regions would be more favorable for information transfer from nearby gauged catchments to the ungauged catchments. In such regions, one can expect a larger range of low variability at intermediate flow percentiles, as observed in the Upper Delaware and Allegheny basins (Fig. 4a, d). Dissimilarity among catchments can also be identified by abnormal CV patterns, as observed in Lower Susquehanna basin (Fig. 4b). High regional variability at low flow and extremely high flow percentiles suggests that similarity in physiographic attributes should be considered while making regionalized predictions at the low flow and extremely high flood events.

Our a priori criteria of catchment selection, i.e., similarity in annual rainfall and runoff, put limits on the size of basins from which the catchments were chosen. Although a limited number of gauged catchments are available within each of our four basins, every catchment has a long and consistent hydrologic record (WY 1970-1988). Ideally, a larger sample size of gauged catchments (if available) within a basin might provide a clearer picture, in quantitative terms, of spatial variability across flow conditions. However, we think it is unrealistic that we will ever have a large number of gauged catchments within a small basin that satisfies our a priori criteria of homogeneity. Moreover, the direct comparison of catchment streamflow and its analysis from an inter-seasonal perspective (Figs. 7 and 8) shows consistency with our observation that regional variability in streamflows is higher at low flow conditions and reduces at higher flows (Fig. 4). Due to the limited number of catchments, the CV patterns in our study might not provide an accurate quantification of variability, but they do provide a preliminary view 
a) Lower Susquehanna - Spatial CV

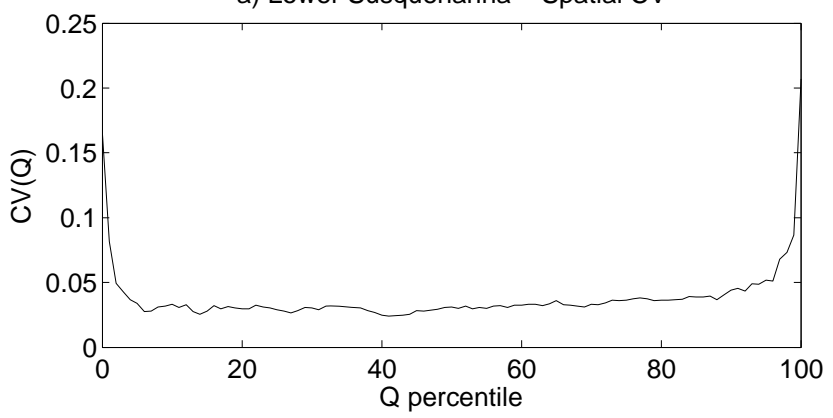

b) Lower Susquehanna - Temporal CV

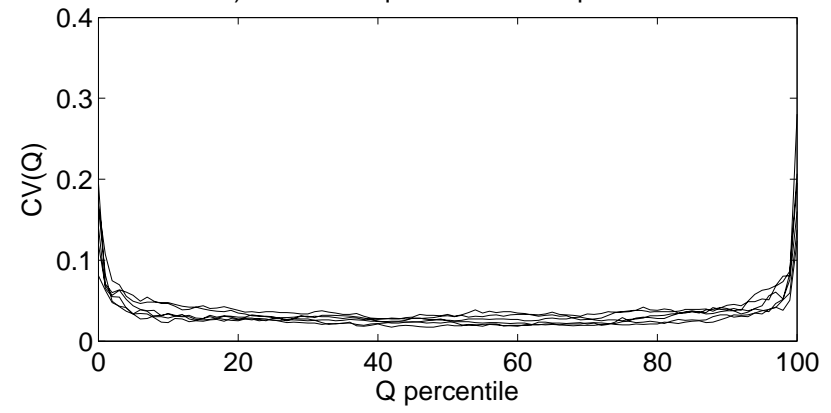

Fig. 9. CV patterns of synthetically generated random time-series that have the same probability distributions as the streamflows of catchments in Lower Susquehanna basin: (a) Spatial CV, (b) Temporal CV.

on the variable nature of hydrologic similarity that is consistent across different basins. In our opinion, one of the main challenges in hydrology, especially from the prediction in ungauged basins (PUB) perspective (Sivapalan et al., 2003), is to work within the constraints of limited measurement locations and learn as much as possible from their observed patterns. We view and interpret the results of this study from that same perspective.

\section{Summary and Conclusion}

This study focused on testing whether stream response similarity among catchments within a region is preserved at all flow conditions. Results show that similarity among catchments is dynamic and highly dependent on the flow conditions. Regional variability in stream response is high at low flow conditions, and it gradually reduces at high flow conditions. Results also suggest that as catchments transition from low to high flow, the dominant control over streamflow variability shifts from evaporative demand to precipitation input. Analysis of the temporal variability of streamflow percentiles shows a similar pattern, i.e., high variability at dry conditions and low variability at wetter conditions. Thus, the evaluation of regional variability over the entire range of streamflow percentiles provides a framework for identifying hydrologic conditions at which stream response among catchments is more likely to be similar. Although our analysis is limited to catchments within the Northeastern United States, the key findings of this study (i.e., dependence of catchment similarity on the flow conditions) should be applicable over a wide range of environments. By identifying the important physical factors that control regional variability in stream response under different wetness conditions, a better understanding and prediction capability of catchment behavior can be achieved at the ungauged sites.

Acknowledgements. This research was supported by the following NSF grants: 0436118 and 0922100 . The authors would like to thank Jeffrey Shaman, Murugesu Sivapalan, Elena Toth (editor) and three anonymous reviewers for providing suggestions to improve this manuscript.

Edited by: E. Toth

\section{References}

Acreman, M. C. and Sinclair, C. D.: Classification of drainage basins according to their physical characteristics; an application for flood frequency analysis in Scotland, J. Hydrol., 84, 365-380, 1986.

Anderson, R. M., Beer, K. M., Buckwalter, T. F., Clark, M. E., McAuley, S. D., Sams, J. I., III, and Williams, D. R.: Water quality in the Allegheny and Monongahela River basins, Pennsylvania, West Virginia, New York, and Maryland, 1996-98: US Geological Survey Circular 1202, p. 32, 2000.

Arnold, J. G. and Allen, P. M.: Automated methods for estimating baseflow and ground water recharge from streamflow records, J. Am. Water Resour. As., 35(2), 411-424, 1999.

Ayers, M. A., Wolock, D. M., McCabe, G. J., Hay, L. E., and Tasker, G. D.: Sensitivity of water resources in the Delaware River Basin to climate variability and change, US Geological Survey WaterSupply Paper 2422, US Geological Survey, Reston, VA, 1994.

Blöschl, G. and Sivapalan, M.: Process Controls on Regional Flood Frequency: Coefficient of Variation and Basin Scale, Water Resour. Res., 33(12), 2967-2980, 1997.

Burn, D.: Catchment similarity for regional flood frequency analysis using seasonality measures, J. Hydrol., 202(1-4), 212-230, 1997.

Burn, D. and Boorman, D.: Estimation of hydrological parameters at ungauged catchments, J. Hydrol., 143(3-4), 429-454, 1993.

Burn, D. and Goel, N.: The formation of groups for regional flood frequency analysis/La formation de groupes pour l'estimation regionale de la frequence des crues, Hydrolog. Sci. J., 45(1), 97112, 2000.

Eaton, B., Church, M., and Ham, D.: Scaling and regionalization of flood flows in British Columbia, Canada, Hydrol. Process., 16(16), 3245-3263, 2002.

Eckhardt, K.: A comparison of baseflow indices, which were calculated with seven different baseflow separation methods, J. Hydrol., 352, 168-173, 2008.

Grayson, R. B., Western, A. W., Chiew, F. H. S., and Blöschl, G.: Preferred states in spatial soil moisture patterns: Local and nonlocal controls, Water Resour. Res., 33(12), 2897-2908, 1997. 
Hargreaves, G. H. and Samani, Z. A.: Estimating potential evapotranspiration, J. Irrig. Drain. E.-ASCE, 108(3), 225-230, 1982.

James, A. L. and Roulet, N. T.: Investigating hydrologic connectivity and its association with threshold change in runoff response in a temperate forested watershed, Hydrol. Process., 21(25), 33913408, 2007.

Kachroo, R., Mkhandi, S., and Parida, B.: Flood frequency analysis of southern Africa: I. Delineation of homogeneous regions, Hydrolog. Sci. J., 45(3), 437-447, 2000.

Laaha, G. and Blöschl, G.: Seasonality indices for regionalizing low flows, Hydrol. Process., 20(18), 3851-3878, 2006.

McDonnel, J. J., Sivapalan, M., Vache, K., Dunn, S., Grant, G., Haggerty, R., Hinz, C., Hooper, R., Kirchner, J., Roderick, M. L., Selker, J., and Weiler, M.: Moving beyond heterogeneity and process complexity: A new vision for watershed hydrology, Water Resour. Res., 43(7), W07301, doi:10.1029/2006WR005467, 2007.

Merz, R. and Blöschl, G.: Regionalisation of catchment model parameters. J. Hydrol., 287(1-4), 95-123, 2004.

Merz, R. and Blöschl, G.: Flood frequency regionalization: spatial proximity vs. catchment attributes, J. Hydrol., 302(1-4), 283306, 2005.

Meyles, E., Williams, A., Ternan, L., and Dowd, J.: Runoff generation in relation to soil moisture patterns in a small Dartmoor catchment, Southwest England, Hydrol. Process., 17(2), 251264, 2003.

Mosley, M. P.: Delimitation of New Zealand hydrologic regions, J. Hydrol., 49(1/2), 173-192, 1981.

Nathan, R. and McMahon, T.: Identification of homogeneous regions for the purposes of regionalisation, J. Hydrol., 121(1-4), 217-238, 1990 .

Nelson, B. W.: Clay mineralogy of the bottom sediments, Rappahannock River, Virginia. Clays and Clay Minerals, 7, 135-147, 1960.

Ogunkoya, O. O.: Towards a delimitation of Southwestern Nigeria into hydrological regions, J. Hydrol., 99(1-2), 165-177, 1988.

Oudin, L., Andreassian, V., Perrin, C., Michel, C., and Le Moine, N.: Spatial proximity, physical similarity, regression and ungaged catchments: A comparison of regionalization approaches based on 913 French catchments, Water Resour. Res., 44(3), W03413, doi:10.1029/2007WR006240, 2008.

Risser, D. W. and Siwiec, S. F.: Water-quality assessment of the Lower Susquehanna River Basin-Environmental setting: U.S. Geological SurveyWater-Resources Investigations Report 944245, p. 50, 1996.

Searcy, J.: Flow-duration curves, manual of hydrology part 2. Lowflow techniques: US Geological Survey Water-Supply Paper, 133, 1959.

Sivapalan, M,. Takeuchi, K., Franks, S. W., Gupta, V. K., Karambiri, H., Laxmi, V., Liang, X., McDonnell, J. J., Mendiondo, E. M., O'Connell, P. E., Oki, T., Pomeroy, J. W., Schertzer, D., Uhlenbrook, S., and Zehe, E.: IAHS Decade on Predictions in Ungauged Basins (PUB), 2003-2012: Shaping an exciting future for the hydrological sciences, Hydrolog. Sci. J., 48(6), 857-880, 2003.
Slack, J., Lumb, A., and Landwehr, J.: Hydro-Climatic Data Network (HCDN): Streamflow Data Set, 1874-1988, USGS WaterResources Investigations Report 93-4076, 1993.

Smakhtin, V.: Low flow hydrology: a review, J. Hydrol., 240(3-4), 147-186, 2001.

Smith, J.: Representation of basin scale in flood peak distributions, Water Resour. Res., 28(11), 2993-2999, 1992.

Stieglitz, M., Shaman, J., McNamara, J., Engel, V., Shanley, J., and Kling, G. W.: An approach to understanding hydrologic connectivity on the hillslope and the implications for nutrient transport, Global Biogeochem. Cy., 17(4), 1105, doi:10.1029/2003GB002041, 2003.

Tromp-van Meerveld, H. and McDonnell, J.: Threshold relations in subsurface stormflow: 1. A 147-storm analysis of the Panola hillslope, Water Resour. Res., 42(2), W02410, doi:10.1029/2004WR003778, 2006.

Uchida, T., Asano, Y., Mizuyama, T., and McDonnell, J.: Role of upslope soil pore pressure on lateral subsurface storm flow dynamics, Water Resour. Res., 40(12), W12401, doi:10.1029/2003WR002139, 2004.

Vogel, R. and Fennessey, N.: Flow-duration curves. I: New interpretation and confidence intervals, J. Water Res. Pl.-ASCE, 120(4), 485-504, 1994.

Vogel, R. and Fennessey, N.: Flow duration curves II: a review of applications in water resources planning, Water Resour. Bull., 31(6), 1029-1039, 1995.

Vogel, R. M. and Sankarasubramanian, A.: Monthly Climate Data for Selected USGS HCDN Sites, 1951-1990. Data set, Oak Ridge National Laboratory Distributed Active Archive Center, Oak Ridge, Tennessee, USA, doi:10.3334/ORNLDAAC/810, available at: http://www.daac.ornl.gov, 2005.

Wagener, T., Sivapalan, M., Troch, P., and Woods, R.: Catchment classification and hydrologic similarity, Geography Compass, 1(4), 901-931, 2007.

Wiltshire, S.: Identification of homogeneous regions for flood frequency analysis, J. Hydrol., 84(3/4), 287-302, 1986.

Winter, T. C.: The concept of hydrologic landscapes, J. Am. Water Resour. As., 37(2), 335-349, 2001.

Wolock, D. M., Winter, T. C., and McMahon, G.: Delineation and evaluation of hydrologic landscape regions in the United States using geographic information system tools and multivariate statistical analyses, Environ. Manage., 34, 71-88, 2004.

Zhang, Y. and Chiew, F.: Relative merits of different methods for runoff predictions in ungauged catchments, Water Resour. Res., 45(7), W07412, doi:10.1029/2008WR007504, 2009. 